\title{
IMPLEMENTASI KEBIJAKAN KREDIT USAHA RAKYAT PADA UMKM DI KABUPATEN BANDUNG
}

\author{
Yayan Mulyana $^{1}$, Abdul Rosid ${ }^{2}$, Nurhayati ${ }^{3}$ \\ 1,2,3 Jurusan Ilmu Administrasi Bisnis Fisip Universitas Pasundan \\ 11yayan.mulyana@unpas.ac.id, ${ }^{2}$ abdul.rosid@unpas.ac.id, ${ }^{3}$ nurhayati@unpas.ac.id
}

\begin{abstract}
This study was made to analyze the implementation of Kredit Usaha Rakyat (KRU) policy on improving the performance of the MSMEs in Warnasari Village, Pangalengan District, Bandung Regency. Based on the results of this study, there are problems related to low MSME performance, seen from it's ability (knowledge + skills). In accordance with the implementation of micro KUR, there is still a lack of knowledge and understanding from business owners when it comes to obtaining information regarding the KUR program. This has happened due to the lack of communication and the socialization from the government through banks. Furthermore, the low motivation of MSMEs/employees, associated with the Micro KUR program itself could burden business expenses. The problem is believed to be caused by the implementation of KUR policy which has not been quite optimal, in terms of communication and bureaucratic structure for it's troublesome administration. The method used for this research was qualitative-descriptive. The purpose of the study is to analyze the implementation of KUR policy on improving the performance of MSMEs in Bandung Regency. The stages of the method in this study involves collecting all of the necessary data, classification according to each of the type and specifications respectively, then analyzing qualitatively along with supporting descriptions and explanations, then the results of the analysis were made and drawn into final conclusions (final results). Based on qualitative analysis, the results show that the KUR program is somewhat ready to be implemented, although there are still aspects that are not feasible, namely the low level of communication and bureaucratic structure, therefore effective communication improvement and simple bureaucratic structures would be required so that it will be sufficient to overcome the occurring root causes of the problems in the KUR policy, therefore increasing the performance of MSMEs. Targeted output is that four important aspects, ranging from communication, resources, disposition / attitude of implementers, and the bureaucratic structure (work mechanism) of the KUR program should be achieved in order for KUR program to be succeed, thus impacting on the improvement of MSMEs performance.
\end{abstract}

Keywords : Implementation, Policy, KUR, Performance, MSMEs

\begin{abstract}
ABSTRAK
Penelitian ini bertujuan untuk menganalisis implementasi kebijakan kredit usaha rakyat untuk meningkatkan kinerja umkm di Desa Warnasari Kecamatan Pangalengan Kabupaten Bandung. Berdasarkan hasil penelitian terdapat permasalahan kinerja UMKM yang rendah ,terlihat dari Kemampuan (knowledge + skill). pengetahuan dan pemahaman para pemilik usaha dalam mendapatkan informasi program KUR. , karena minimnya komunikasi sosialisasi pihak pemerintah melalui perbankan. Selanjutnya rendahnya motivasi pelaku UMKM/karyawan dikaitkan dengan program KUR Mikro dapat membebani pengeluaran
\end{abstract}


usaha. Permasalahan tersebut disebabkan oleh implementasi kebijakan KUR belum optimal, dalam hal komunikasi serta struktur birokrasi dalam pengurusan/adminstrasi yang sulit dan berat. Metode penelitian menggunakan kualitatif-deskriftif. Berdasarkan analisis kualitatif mendapatkan hasil bahwa program Kredit Usaha Rakyat (KUR) mikro sudah cukup siap untuk diimplementasikan, walaupun masih terdapat aspek-aspek yang belum layak yakni masih rendahnya komunikasi dan struktur birokrasi, untuk itu diperlukan peningkatan komunikasi yang efektif dan struktur birokrasi yang sederhana, sehingga cukup untuk menangani penyebab masalah yang terjadi dalam implementasi kebijakan KUR sehingga kinerja UMKM meningkat. Luaran yang ditargetkan bahwa empat aspek mulai komunikasi, sumberdaya, disposisi/sikap pelaksana, serta struktur birokrasi (mekanismen kerja) program KUR dapat tercapai, sehingga berdampak terhadap peningkatan kinerja UMKM.

Kata Kunci : Implementasi, Kebijakan, KUR, Kinerja, UMKM

\section{PENDAHULUAN}

$$
\begin{aligned}
& \text { Usaha mikro kecil menengah } \\
& \text { memiliki peranan strategis dalam } \\
& \text { meningkatkan pendapatan dan kesempatan } \\
& \text { kerja, penanggulan kemiskinan, seta } \\
& \text { perluasan lapangan kerja di Indonesia. }
\end{aligned}
$$

Kenyataan tersebut menggambarkan

bahwa UMKM telah mampu membuka kesempatan kerja bagi masyarakat daerah. Pemerintah perlu memberikan dukungan terhadap UMKM, yang dapat berupa penguatan teknologi dan informasi, akses kepada sumber keuangan, dan akses pasar yang bagus. Karena memiliki banyak kelemahan UMKM tidak dapat bersaing dengan usaha besar. Jika tidak diperbaiki kesenjangan yang terjadi akan semakin parah. Berkenaan dengan berbagai permasalahan tentang sumber keuangan kondisi UMKM menghadapi kendala akses permodalan terutama dari sisi secara administrasi yang dianggap sulit maupun nilai pinjaman yang terbatas. Hal tersebut tentunya menjadi sesuatu yang dianggap dapat menghambat kegiatan yang dilakukan oleh UMKM, karena tidak semua pelaku UMKM memiliki modal yang cukup untuk mengembangkan usaha, dan hal ini tentu hanya dapat diupayakan melalui pemberian pinjaman darilembaga terkait yaitu perbankan. Untuk mengatasi permodalan tersebut, pemerintah mengeleluarkan suatu kebijakan KUR (Kredit Usaha Rakyat) melalui Keputusan Presiden Nomor 19 Tahun 2015 sebagai revisi Keputusan Presiden Nomor 14 Tahun 2015 tentang Komite Kebijakan Pembiayaan bagi Usaha Mikkro Kecil dan Menegah. Melalui kebijakan tersebut, Bank Rakyat Indonesia (BRI) ditunjuk sebagai salah Bank Pelaksana khususnya KUR Mikro. makro ekonomi dikelola dengan baik, stabil, dan dapat diprediksi; informasi yang dapat dipercaya dan mudah diakses, dan lingkungan sosial mendorong dan menghargai keberhasilan usaha tersebut. Sejalan dengan Studi yang dilakukan oleh Maupa (2004) faktor 
eksternal yang mempengaruhi

kinerja UMKM menunjukkan: (1)

Karakteristik individu manajer/pemilik, karakteristik perusahaan, lingkungan eksternal bisnis, dan dampak kebijakan ekonomi dan sosial mempunyai pengaruh langsung, positif, dan signifikan terhadap strategi bisnis dan pertumbuhan usaha; (2) Karakterisitik perusahaan, dan dampak kebijakan sosial dan ekonomi mempunyai pengaruh langsung yang negatif terhadap strategi bisnis; dan (3) Strategi bisnis mempunyai pengaruh langsung positif, dan signifikan terhadap pertumbuhan perusahaan. Demikian juga hal nya pemilik UMKM yang ada di lingkungan Desa Warnasari Kecamatan Pangalengan Kabupaten Bandung dalam melaksanakan usahanya masih lemah, konsep kewirausahaan dengan mengelola usaha kecil belum dapat diaplikasikan sepenuhnya. Setiap bisnis atau usaha tidak dijamin seratus persen berhasil.

Berdasarkan hasil penelitian terdapat permasalahan kinerja UMKM di desa warnasari yaitu sebagai berikut :

\section{Kemampuan Reality (knowledge +} skill) Rata-rata pemilik usaha mikro kecil dan menengah serta karyawan memiliki tingkat pendidikan yang cukup rendah, berdasarkan data yang diperoleh bahwa dari sejumlah 20 (dua puluh) UMKM, tingkat pendidikan bervariasi dari SD-SMP-SMA, artinya dengan tingkat pendidikan seperti tersebut pengetahuan maupun pemahaman terhadap pekerjaan akan rendah. Berkaitan dengan implementasi KUR mikro masih rendahnya pengetahuan dan pemahaman para pemilik usaha untuk mendapatkan atau mengurus KUR yang dimaksud.

\section{Faktor Motivasi}

Motivasi yaitu sebagai suatu sikap yang ditunjukkan baik dari pimpinan maupun karyawan terhadap situasi kerja di lingkungan usaha. Berdasarkan hasil penelitian diperoleh bahwa motivasi pelaku UMKM maupun karyawan lingkungan usaha di Kabupaten Bandung masih rendah, hal ini dapat dibuktikan bahwa sikap mereka yang tidak pro (kontra) terhadap usaha yang dijalankan, artinya mereka beranggapan bahwa usaha tersebut yang penting berjalan apa adanya, tidak ada pemikiran ke depan bagaimana kelanjutan maupun prospek usahanya. Kondisi seperti ini dapat berdampak langsung terhadap capaian hasil pekerjaan dari target maupun realisasi.

\section{Berdasarkanmpermasalahan-}

permasalahan tersebut, selanjutnya peneliti kemukakan bahwa rendahnya atau turunnya kinerja dari pemilik UMKM, disebabkan karena implementasi kebijakan Kredit Usaha Rakyat (KUR) belum dilaksanakan secara optimal, hal ini berkaitan dengan komunikasi yang 
dibangun antara pihak pelaksana (Bank) dengan calon peminjam belum berjalan efektif, dilihat minimnya sosialisasi tentang KUR Mikro kepada para pemilik usaha serta struktur birokrasi dalam pengurusan/ adminstrasi yang sulit dan berat seperti harus ada jaminan dan lain-lain. Tujuan penelitian adalah untuk mengetahui implementasi kebijakan kreidt usaha rakyat pada UMKM di Kabupaten Bandung.

\section{KAJIAN TEORI}

\section{Kebijakan}

Selanjutnya menurut Agustino sebagaimana mengutip pendapat Carl Friedrich yang mengartikan kebijakan sebagai berikut : Kebijakan adalah serangkaian tindakan/kegiatan yang diusulkan oleh seseorang, kelompok, atau pemerintah dalam suatu lingkungan tertentu dimana terdapat hambatan-hambatan (kesulitan-kesulitan) dan kemungkinankemungkinan (kesempatan-kesempatan) dimana kebijakan tersebut diusulkan agar berguna dalam mengatasinya untuk mencapai tujuan yang dimaksud (Friedrich dalam Agustino, 2012: 7 ).

Selanjutnya menurut Fred.R.David, (2008 : 17 ) kebijakan (policy) adalah alat untuk mencapai tujuan tahunan. Kebijakan mencakup pedoman, peraturan, dan prosedur yang dibuat untuk mendukung usaha mencapai tujuan yang telah ditetapkan. Kebijakan adalah pedoman untuk pengambilan keputusan dan memberi jawaban atas situasi yang rutin dan berulang. Mengacu kepada unsur-unsur kebijakan menurut para ahli, maka peneliti perpendapat bahwa kebijakan adalah serangkaian tindakan terarah yang mempunyai tujuan dan cara-cara untuk mencapai tujuan tersebut dalam kaitannya untuk memecahkan atau menyelesaikan suatu permasalahan dalam lingkungan tertentu pada masyarakat.

\section{Kredit Usaha Rakyat}

Kredit Usaha Rakyat adalah kredit/pembiayaan modal kerja dana/atau investasi kepada debitur individu/perseorangan, badan usaha dan/kelompok usaha yang produktif dan layak namun belum memiliki agunan tambahan atau agunan tambahan belum cukup. Tujuan dilaksanaknnya program KUR antara lain adalah untuk meningkatkan dan memperluas akses pembiayaan kepada usaha produktif, meningkatkan kapasitas daya saing UMKM, dan mendorong pertumbuhan ekonomi dan penyerapan tenaga kerja. Program Kredit Usaha Rakyat (KUR) merupakan program prioritas dalam mendukung kebijakan pemberian kredit/pembiayaan kepada sector usaha mikro, kecil dan menengah. Pada tahun 2015, tercapainya target penyaluran Kredit Usaha Rakyat sebesar Rp. 20 triliun menjadi salah satu target IKU Deputi Bidang Koordinasi Ekonomi Makro dan 
Keuangan. Target tersebut terpenuhi dengan jumlah penyaluran samapai dengan 31 Desember 2015 sebesar Rp. 22,75 triliun (113, 75 persen). Jumlah tersebut dicapai dalam empat bulan penyaluran KUR oleh 3 Bank BUMN . Bank dengan kinerja penyaluran KUR tertinggi adalah Bank BRI dengan penyaluran sebesar Rp. 16,2 triliun. Manfaat program KUR adalah untuk meningkatkan dan memperluas akses wirausaha seluruh sector usaha produktif kepada pembiayaan perbankan, mendorong pertumbuhan ekonomi, dan meningkatkan daya saing UMKM. (https://kur.ekon.go.id/kebijakan-kur\#)

\section{Implementasi Kebijakan KUR}

Berdasarkan Peraturan Menteri Koordinator Bidang Perekonomian Nomor 11 Tahun 2017 tentang Pedoman Pelaksanaan Kredit Usaha Rakyat, penerima KUR terdiri dari UMKM, calon tenaga kerja Indonesia yang akan bekerja di luar negeri, calon pekerja magang di luar negeri, anggota keluarga dari karyawan/karyawati yang berpenghasilan tetap atau bekerja sebagai tenaga kerja Indonesia, tenaga kerja Indonesia yang purna bekerja di luar negeri, pekerja yang terkena pemutusan hubungan kerja, usaha mikro,kecil, dan menengah di wilayah perbatasan dengan negara lain: dan/atau kelompok usaha seperti Kelompok Usaha Bersama (KUBE), Gabungan Kelompok Tani dan Nelayan (GAPOKTAN), dan kelompok usaha lainnya. Adapun peraturan perundangan yang terkait dengan dengan pelaksanaan program KUR, antara lain: a) Kepres Nomor 14 Tahun 2015 tentang Komite Kebijakan Pembiayaan Bagi Usaha Mikro, Kecil dan Menengah; b) Kepres Nomor 19 Tahun 2015 sebagai revisi Kepres Nomor 14 Tahun 2015 tentang Perubahan Atas Kepres Nomor 14 Tahun 2015 tentang Komite Kebijakan Pembiayaan Bagi Usaha Mikro, Kecil dan Menengah; c) Permen Koordinator Bidang Perekonomian Nomor 11 Tahun 2017 tentang Pedoman Pelaksanaan Kredit Usaha Rakyat; dan d) Permenkeu Nomor 180/PMK.05/2017 tentang Tata Cara Pembayaran Subsidi Bunga untuk KUR.

Bank Rakyat Indonesia sebagai salah satu Bank yang ditunjuk oleh Pemerintah (Kementrian Koperasi dan UMKM), bertugas menyalurkan kredit modal kerja atau kredit investasi dengan plafon kredit sampai dengan Rp. 500 juta yang diberikan kepada usaha mikro, kecil dan koperasi yang memiliki usaha yang produktif yang akan mendapat penjaminan dari perusahaan penjamin. Penjamin dimaksud adalah Perum Jaminan Kredit Indonesia, PT Asuransi Kredit Indonesia, PT Penjaminan Kredit Daerah dan lainlain yang tersebar di seluruh daerah/wilayah Indonesia. Sebanyak empatpuluh satu Bank yang ditunjuk oleh Pemerintah sebagai penyalur, tiga 
diantaranya adalah Bank Rakyat Indonesia, Bank Negara Indonesia, dan Bank Mandiri.

Kinerja

Kinerja adalah hasil yang diperoleh oleh suatu organisasi baik organisani tersebut bersifat profit oriented dan non profit oriented yang dihasilkan selama satu periode waktu. Secara lebih tegas Amstron dan Baron, mengatakan Kinerja merupakan hasil pekerjaan yang mempunyai hubungan kuat dengan tujuan strategis organisasi, kepuasan konsumen dan memberikan kontribusi ekonomi (Amstrong dan Baron, $1998: 15)$.

Berikut ini adalah beberapa faktor yang dapat mempengaruhi kinerja dari pegawai didalam suatu organisasi atau perusahaan. Menurut Mangkunegara (2005:13-14) ada beberapa faktor yang mempengaruhi kinerja, yaitu sebagai berikut. a) Faktor Kemampuan (ability). Secara psikologis, kemampuan (ability) terdiri dari: a) Faktor Motivasi (Motivation) b)Motivasi diartikan sebagai suatu sikap (attitude) pimpinan dan karyawan terhadap situasi kerja (situation) di lingkungan organisasinya.

\section{METODE PENELITIAN}

Penelitian ini menggunakan metode kualitatif-deskriptif. Penetapan lokasi penelitian Implementasi Kebijakan KUR terhadap Peningkatan Kinerja UMKM Di
Desa Warnasari Kecamatan Pangalengan Kabupaten Bandung, dilakukan pada pihak pelaksana (Bank) di Bandung serta pemilik usaha di Kabupaten Bandung. Peneliti mendapatkan informasi dari informan yang ditunjuk sebagai berikut : pihak pelaksana (Bank), Kordinator lapangan (aparat desa), serta pemilik usaha. Unit yang dianalisis adalah pihak pelaksana (Bank), serta pemilik usaha sebanyak 20 UMKM. Teknik pengumpulan data yang digunakan adalah wawancara yang terstruktur dan tidak terstruktur. Observasi berupa pengamatan langsung, serta dokumentasi sebagai tambahan data penunjang. Analisa data dalam penelitian kualitatif-deskriptif yaitu menggambarkan teori dengan kondisi di lapangan mengenai implementasi kebijakan KUR terhadap peningkatan kinerja UMKM. Hal ini dilakukan dengan menggunakan langkah-langkah maupun tahapan-tahapan seperti mengumpulkan data yang diperlukan, kemudian digolongkan menurut jenis dan spesifikasinya, kemudian dianalisis secara kualitatif dengan menguraikan dan penjelasan yang mendukung, hasil analisisnya dibuat/ditarik kedalam kesimpulan (hasil akhir penelitian).

\section{PEMBAHASAN}

Kegiatan penelitian ini dilaksanakan di Desa Warnasari Kecamatan Pangalengan Kabupaten Bandung. Obyek penelitian ini 
adalah pemilik Usaha Mikro Kecil Menengah (UMKM) sebanyak 20 (dua puluh) UMKM. Poduk yang dihasilkan UMKM di daerah tersebut beragam mulai dari makanan, minuman, handycraft, juga pengolahan (kopi, kotoran sapi). Adapun bidang usaha, jenis produk UMKM. peneliti jelaskan kedalam tabel sebagai berikut :

Tabel .1 Usaha dan bidang usaha serta jenis produk/jasa yang dihasilkan

\begin{tabular}{|c|c|c|c|c|}
\hline No & Nama Perusahaan & $\begin{array}{l}\text { Bidang } \\
\text { Usaha }\end{array}$ & $\begin{array}{l}\text { Jenis } \\
\text { Produk/Ja } \\
\text { sa }\end{array}$ & $\begin{array}{l}\text { Nama pemilik \& Alamat } \\
\text { Perusahaa }\end{array}$ \\
\hline 1 & Anyaman Bambu & Perhutanan & Peralatan & Cucu Wanasari RW 02 \\
\hline 2 & Asesoris & Keterampilan & Handycraft & $\begin{array}{l}\text { Asep Rukmana Wanasari } \\
\text { RW } 02\end{array}$ \\
\hline 3 & Konpeksi & Sandang & Pakaian & $\begin{array}{l}\text { Agus Warjono Wanasari RW } \\
02\end{array}$ \\
\hline 4 & Pengolahan Kopi & Perkebunan & Minuman & $\begin{array}{l}\text { Encang Dasman Wanasari } \\
\text { RW } 02\end{array}$ \\
\hline 5 & Asesoris & Keterampilan & Handycraft & Pandi Wanasari RW \\
\hline 6 & Kerajinan Besi & Keterampilan & Perlengkapan & Asep Wanasari RW 04 \\
\hline 7 & Manisan Terong & Pertanian & Makanan & Enok Munjul RW 05 \\
\hline 8 & Anyaman Bambu & Perhutanan & Peralatan & Ating Munjul RW 05 \\
\hline 9 & Keripik & Pertanian & Makanan & $\begin{array}{l}\text { Asep Purnama Cipangisikan } \\
\text { RW } 0\end{array}$ \\
\hline 10 & Keripik & Pertanian & Makanan & $\begin{array}{l}\text { Cucu Aisyah Cipangisikan } \\
\text { RW } 08\end{array}$ \\
\hline 11 & Asesoris & Keterampilan & Handyccraft & Nana Cibeunying RW 09 \\
\hline 12 & Pengolahan Kopi & Perkebunan & Minuman & Utep Citiis RW 10 \\
\hline 13 & Bokasi & Peternakan & $\begin{array}{l}\text { Non Makanan } \\
\& \text { Minuman }\end{array}$ & $\begin{array}{l}\text { Agus Hasan Cipangisikan } \\
\text { RW } 11\end{array}$ \\
\hline 14 & Keripik & Pertanian & Makanan & $\begin{array}{l}\text { Eem Karmanah Cipangisikan } \\
\text { RW }\end{array}$ \\
\hline 15 & Daur Ulang Sampah & $\begin{array}{l}\text { Industry } \\
\text { kreatif }\end{array}$ & Handycraft & Eros Wanasari RW 12 \\
\hline
\end{tabular}




$\begin{array}{lllll}16 & \text { Kue Basah } & \text { Pertanian } & \text { Makanan } & \text { Ai Ipah Padahurip RW 13 } \\ 17 & \text { Daur Ulang Sampah } & \begin{array}{l}\text { Industry } \\ \text { kreatif }\end{array} & \text { Handycraft } & \text { Nunung Padahurip RW 13 } \\ & & \text { Peternakan } & \text { Minuman } & \text { Osin Padahurip RW 13 } \\ 18 & \text { Herbal Cacing } & \text { Pertanian } & \text { Makanan } & \text { Nene Cipangisikan RW 14 } \\ 19 & \text { Kerupuk Kentang } & \text { Perikanan } & \text { Makanan } & \text { Iim Wanasari RW 15 } \\ 20 & \text { Baso Ikan } & \text { Man } & \end{array}$

Sumber : Data Hasil Penelitian tahun 2019, diolah kembali oleh Peneliti.

Tabel di menjelaskan bahwa pelaku UMKM sangat bervariasi dalam bidang usaha/jenis produk atau jasa yang dihasilkan. Total penjualan tahunan, dan status usaha, maka beberapa kriteria 20 (dua puluh) UMKM yang berada di Desa Warnasari Kecamatan Pangalengan Kabupaten Bandung sebanyak 16 (enam belas) UMKM termasuk kriteria Usaha Mikro. Sedangkan sisnya 4 (empat) UMKM termasuk kriteria Usaha Kecil, dan Usaha Menengah. Salah satu Indikator Usaha Mikro adalah kegiatan yang dilakukannya berskala kecil dan bersifat tradisional dan informal, dalam arti belum terdaftar, belum tercatat dan belum berbadan hukum. Hasil penjualan usaha tersebut paling banyak Rp. 100.000.000,.Hasil observasi dan wawancara kepada 20 (dua puluh) UMKM yang berada di Desa Warnasari Kecamatan Pangalengan Kabupaten Bandung sebanyak 16 (enam belas) UMKM atau 3,2 persen tidak pernah berurusan dengan pihak perbankan dalam fasilitasi pinjaman dana (kredit), sedangkan sisanya sebanyak 4 (empat), yaitu 2 (dua) usaha pengolahan kopi, 1 (satu) usaha pengolahan kotoran sapi, serta 1 (satu) usaha konfeksi pernah mendapatkan pinjaman dana dari pihak perbankan. Berdasarkan data yang diperoleh tersebut, artinya persentase penerima kucuran kredit usaha rakyat (KUR) mikro kepada pemilik usaha UKMK sangat kecil sebesar 0,8 persen. Dari beberapa kriteria tersebut, persoalan lain yang menjadi perhatian agar UMKM tersebut dapat berkembang lebih cepat, maka pembiayaannya harus dipikirkan terutama oleh pengambil kebijakan. Selanjutnya, perhatian berbagai pihak terhadap UMKM dapat dilihat dari kebijakan pemerintah dan perbankan yang memberikan kredit kepada UMKM.

Salah satu kegiatan BRI dalam pelayanan penyimpanan dan peminjaman adalah untuk kegiatan usaha Mikro, yaitu usaha yang menyediakan fasilitas kredit maksimum Rp. 50.000.000,- kepada pengusaha mikro dan perorangan yang berpenghasilan rendah. Sesuai dengan tujuan dan aktivitasnya, penyaluran kredit paling banyak kepada sector UMKM yang besarnya mencapai 79,99 persen pada tahun 2000 menjadi 86,44 persen pada 
tahun 2004. Pengusaha yang ingin mendapatkan dana pinjaman dari bank ini dapat menghubungi semua kantor unit BRI yang terdapat di pedesaan maupun di perkotaan.

Penyaluran Kredit Usaha Rakyat, sumber pendanaanya berasal dari Simpanan Dana Pihak ketiga (DPK) dari masyarakat (nasabah) kepada perbankan dimana dana tersebut dioperasionalisasikan/dititipkan kepada masyarakat (debitur UMKM) yang memiliki kegiatan ekonomi produktif dalam bentuk pinjaman dengan sumber pengembaliannya berasal dari hasil keuntungan usahanya. KUR diberikan kepada nasabah/debitur yang memiliki kegiatan ekonomi produktif yang feseable untuk dibiayai dan memiliki potensi yang prospektif kedepan, dimana dari hasil kegiatan usahanya dapat menghasilkan keuntungan.

Ketentuan KUR ini diperjelas bahwa calon debitur adalah individu yang melakukan usaha produktif yang layak serta memiliki legalitas yang lengkap, seperti KTP/SIM, KK, dan lama usaha minimal 6 bulan. Selanjutnya, KUR linkage program (channelling) bahwa calon debitur adalah end user yang tidak sedang menikmati KMK atau KI (Kredit Modal Kerja/Kredit Investasi) dana tau Kredit Pemerintah, namun Kredit Konsumtif diperbolehkan. Lembaga linkage, diperbolehkan sedang mendapatkan pembiayaan dari Perbankan maupun Kredit Program Pemerintah. Sedangkan legalitas, end user sesuai dengan KUR Mikro/Ritel.

Persyaratan Kredit KUR Mikro adalah plafon kredit maksimal Rp. 20 juta, suku bunga efektif maksimal 22 persen per tahun, jangka waktu dan jenis kredit : a. KMK maks 3 tahun; KI mak 5 tahun dalam hal perpanjangan, suplesi serta restrukturisasi, KMK maks 6 tahun; KI maks 10 tahun. Untuk agunan : a. Pokok, dapat berupa agunan pokok apabila sesuai keyakinan Bank Proyek yang dibiayai cashflownya mampu memenuhi seluruh kewajiban kepada Bank (layak). KUR Linkage Program (Channelling), plafon kredit sesuai dengan ketentuan KUR mikro. Jangka waktu dan jenis kredit KMK maks 3 tahun; KI mak 5 tahun dalam hal perpanjangan, suplesi serta restrukturisasi, KMK maks 6 tahun; KI maks 10 tahun. Suku bunga sesuai dengan ketentuan KUR Mikro. Agunan pokok, piutang kepada nasabah, dan agunan tambahan sesuai dengan ketentuan pada Bank Pelaksana.

Pada Umumnya setiap kredit memerlukan jaminan namun khusus untuk KUR diatur sebagai berikut :
a. KUR TKI \& MIKRO jaminannya merupakan usaha ybs. (first way out)
b. KUR Ritel diatur: 1) Maksimum Rp.50 
juta sd 100 juta berupa AJB/SHGB/SHM; 2) Maksimum Rp.100 juta sd Rp.500 juta wajib SHGB/SHM

\section{Pembatasan penyaluran KUR}

a. KUR penempatan TKI sebesar Cost Structure yang dikeluarkan BNP2TKI sesuai dengan negara tujuan dengan besar maksimum Rp.25 juta

b. KUR Mikro s/d maksimum Rp.50 juta yang dapat disuplesi sebanyak 4 kali atau maksimum akumulasi Rp.200 juta

c. KUR Ritel mulai diatas Rp.50 juta sd Rp. 500 juta

Jenis pembiayaan dapat bertujuan untuk keperluan Modal Kerja dan atau Investasi untuk menunjang usaha debitur dengan jangka waktu penyelesaian / angsuran dapat disesuaikan karakteristik cashflow nasabah dhi dapat dilakukan secara angsuran pokok bunga setiap bulan (aflopend) atau bayar sekaligus pada saat jatuh tempo (Yarnen / Bayar Panen khusus pertanian).

Petugas kredit melakukan pre screening terhadap calon debitur dengan mengidentifikasi siklus usaha dst, dan setelah proses Analisa dan mengidentifikasi kebutuhannya dilakukan persetujuan dan perjanjian kredit. Setelah pencairan kredit petugas ada kewajiban untuk memonitor/berkunjung kepada debitur dimana untuk debitur KUR Mikro minimal 6 bulan sekali dikunjungi sementara untuk KUR Ritel minimal 1 tahun sekali dalam rangka memonitor perkembangan usaha, perkembangan jaminan pasca pencairan kredit juga melihat potensi jika untuk melakukan tambahan / top up kredit. Kendalanya debitur memerlukan waktu untuk melengkapi legalitas usahanya dan dari sisi jaminan sering ditemukan masih berbentuk AJB dan atau SHM yang masih tercantum nama orang lain Debitur baik dari sisi omset, rata-rata mengambil keuntungan, biaya operasional, rata-rata kas, rata-2 pembelanjaan, data tagihan, data data hutang dagang, daftar asset serta daftar pinjaman yang terinformasi dari laporan SLIK OJK / BI Checking, petugas bank membantu untuk membuatkan neraca keuangan dan laporan rugi laba calon debitur yag dikonfirmasi serta disetujui oleh debitur. Melengkap penjelasan mengenai Kredit Usaha Rakyat (KUR), dijelaskan tentang ketentuan umum KUR tahun 2018 serta Informasi KUR lainnya dalam gambar sebagai berikut : 


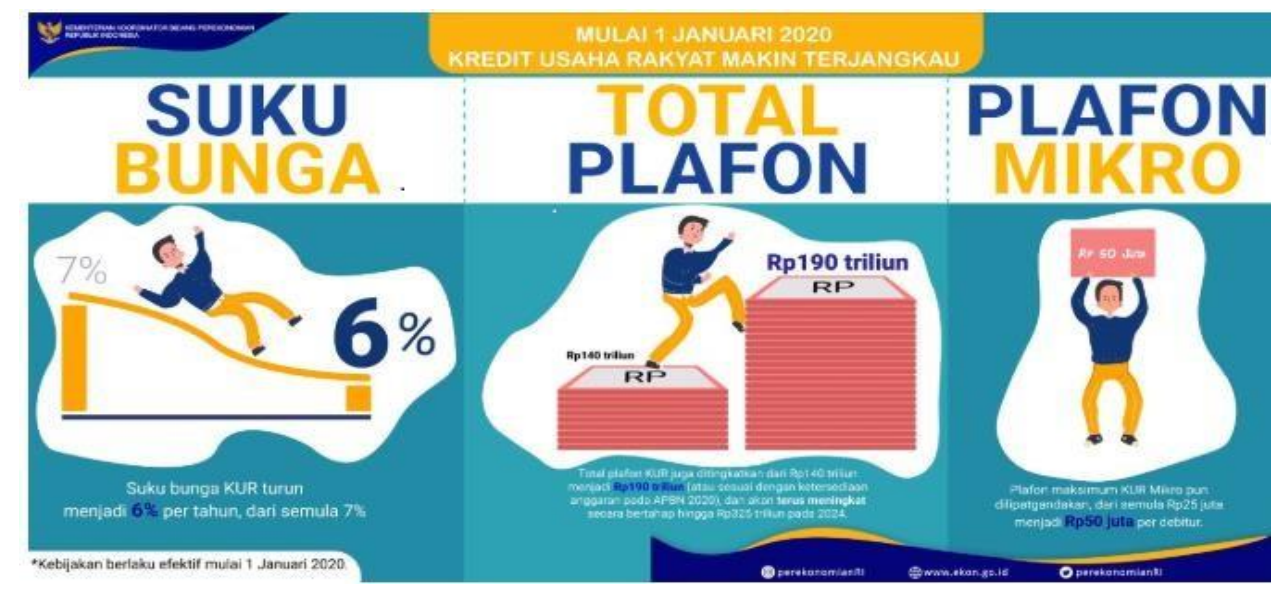

Gambar 1. Informasi mengenai KUR

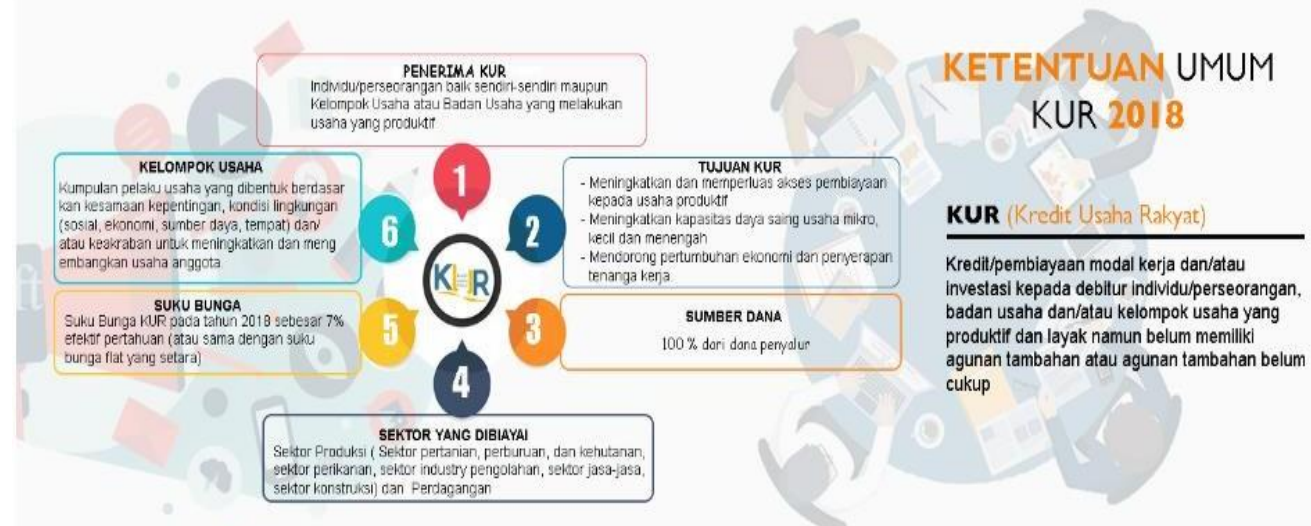

Gambar 2. Ketentuan Umum KUR 2018

Usaha Mikro, Kecil dan Menegah (UMKM) memiliki peran dan kontribusi yang penting dalam perekonomian Indonesia. Peranan strategis tersebut tercermin dari total unit usaha UMKM mencapai 99,9 persen dari total unit usaha dan kontribusi penyerapan tenaga kerja di UMKM sebesar 96,9 persen dari total penyerapan tenaga kerja serta kontribusi UMKM terhadap PDB sebesar 60,34 persen (BPS, 2017) . Strategisnya peranan UMKM dalam perekonomian nasional mendorong pemerintah untuk terus menerus mengembangkan UMKM. Dalam rangka mempercepat pengembangan
UMKM sejalan dengan akan diterbitkannya RUU Cipta lapangan kerja, Komite Kebijakan Pembiayaan yang diketuai oleh Mentri Koordinator Bidang perekonomian memutuskan untuk merubah kebijakan KUR yang lebih pro kerakyatan (https://kur.ekon.go.id/perubahan-

kebijakan- kredit-usaha-rakyat-kur-tahun2020).

Pemerintah menargetkan penyaluran KUR hingga Rp. 325 triliun selama lima tahun ke depan. Pemberian KUR tersebut akan diberlakukan secara bertahap hingga 2024. Peningkatan target penyaluran KUR ini dikuti dengan beberapa relaksasi 
kebijakan. Kebijakan itu diantaranya peningkatan maksimum plafon KUR mikro (dari Rp. 25 juta menjadi Rp. 50 juta per debitur) dan peningkatan akumulasi plafon KUR mikro (dari Rp.100 juta menjadi Rp.200 juta per debitur). Perubahan ini berlaku sejak 2 Januari 2020. Selanjutnya di tahun 2020, pemerintah menurunkan suku bunga KUR menjadi 6 persen. Peningkatan tidak terjadi hanya pada nominal penyaluran saja, tetapi juga UMKM penerima KUR dari 2,4 juta debitur pada tahun 2014, menjadi 4,4, juta debitur pada tahun 2018, dengan total akumulasi debitur sampai dengan Desember 2019 mencapai 18,6 juta akad kredit atau sebanyak 12,9 juta orang, (Koran Pikiran Rakyat, 22 Januari 2020). Berdasarkan peningkatan tersebut, dapat dianalisis bahwa capaian KUR diidominasi oleh UMKM yang baru mengakses pembiayaan, bukan UMKM yang berulang. Analisis lainnya bahwa pangsa penyaluran UMKM terutama di sector produksi mengalami peningkatan.

\section{Analisis Implementasi Kebijakan}

Berdasarkan hasil penelitian menunjukkan komunikasi yang dibangun pihak Bank dengan pemilik UMKM sudah cukup efeektif. Komunikasi yang dilakukan berupa on the spot, yaitu penjelasan langsung kepada debitur/pemilik UMKM mengenai penyaluran KUR dari mulai syarat, ketentuan, prosedur dan lain-lain., pihak Bank mendatangai langsung sasaran yang dimaksud, maupun komunikasi melalui informasi yang disebarluaskan melalui berbagai media, baik media cetak maupun non cetak. Media dimaksud berupa brosur, spanduk, baligo, koran dan lain-lain. Secara umum komunikasi yang dilaksanakan oleh pihak pelaksana/BRI sudah efektif kepada calon debitur/pemilik UMKM/masyarakat luas utamanya informasi penyaluran KUR mikro.

Berdasarkan hasil penelitian, kemampuan sumber daya manusia yang dimaksud adalah implementor/pegawai BRI dalam melaksanakan tugas maupun pekerjaan dalam kaitannya dengan KUR. Kemampuan pegawai bisa dilihat dari sisi kualitas maupun kuantitas. Secara kualitas pegawai mampu menjalankan tugas secara optimal dan bertanggungjawab, sedangkan secara kuantitas, dilihat dari jumlah pegawai yang menangani KUR.

Pegawai/sumber daya manusia sudah cukup memadai dalam kemampuan baik pengetahuan maupun ketrampilan tentang program KUR. Selanjutnya pegawai dapat dilihat dari motivasinya serta inisiatif dalam menangani pekerjaan KUR. Sumber lain yang tidak kalah pentingnya adalah sumber non manusia (finansial). Bagi pihak pelaksana (BRI) yang ditunjuk oleh pemerintah tentu mempunyai kecukupan dana untuk kembali disalurkan kepada pemilik UMKM melalui program KUR mikro. 
Dana yang disediakan pemerintah untuk disalurkan ke BRI menjadi salah satu kekuatan bahwa modal tersebut disebut modal investasi. Berdasarkan hasil penelitian, kecukupan modal investasi ini di era Pandemi Covid-19 pun sejalan dengan kebijakan pemerintah pro rakyat yaitu percepatan UMKM naik kelas, untuk tahun 2020 pemerintah menargetkan penyaluran KUR hingga Rp. 325 triliun selama lima tahun ke depan. KUR tersebut akan dilakukan secara bertahap hingga tahun 2024. Selanjutnya kebijakan pemerintah (KUR mikro) adalah menurunkan tingkat suku bunga menjadi 6 persen, meningkatkan maksimum plafon KUR mikro semula Rp. 25 juta menjadi Rp. 50 juta per debitur. Perubahan kebijakan KUR ini mulai diberlakukan sejak 2 Januari 2020. Dengan kecukupan kredit modal kerja maupun kredit investasi. Kebijakan yang diarahkan kepada UMKM diperlukan untuk mencapai pertumbuhan ekonomi nasional yang inklusif dan berbasis ekonomi pasar yang adil.

Berdasarkan hasil penelitian, bahwa pegawai mempunyai tingkat kejujuran, komitmen dan demokratis yang tinggi terhadap operasional pekerjaan KUR mikro dalam rangka kesuksesan sebuah program maupun kebijakan.

Struktur birokrasi organisasi umumnya terdiri atas dua aspek penting yaitu mekanisme atau SOP, serta struktur organisasi atau pembagian kerja. Berdasarkan hasil penelitian bahwa standar operating procedure/SOP KUR mikro di BRI sudah dilaksanakan berdasarkan SOP BRI Pusat. Mekanisme yang dibuat oleh BRI sangat sederhana dan sistematis sehingga dapat dipahami oleh masyarakat luas termasuk pemilik UMKM, penjelasan mulai dari pengajuan permohonan, analisa kredit melalui 5-C (Character, Capital, Collateral, Condition, dan Capacity), pencairan kredit, serta evaluasi pasca kredit sudah dilaksanakan oleh BRI.

Selanjutnya struktur birokrasi atau organisasi dalam pembagian kerja sudah dilaksanakan sesuai tugas dan fungsi masingmasing. Desain organisasi BRI untuk pelayanan maupun urusan KUR mikro dibuat sederhana dengan harapan tidak berbelitbelit ketika pemilik UMKM mengurus KUR mikro. Sejalan dengan sederhananya struktur organisasi berdasarkan tingkatannya, maka pada saat urusan KUR mikro ini dilaksanakan hanya melibatkan Kepala Unit, Supervisor, Teller, Customer Service, dan Mantri KUR.

\section{Analisis Kinerja}

Berdasarkan hasil observasi dan wawancara dengan pemilik usaha, dan karyawan UMKM Kabupaten Pangalengan, berikut ini peneliti kemukakan kedalam bentuk tabel alasan mengenai kemampuan atau ketidakmampuan. 
Tabel 2. Kemampuan

\begin{tabular}{ll}
\hline \multicolumn{1}{c}{ Kemampuan } & \multicolumn{1}{c}{ Alasan } \\
\hline Mampu & Pelaku usaha mampu memperoleh dan mengarahkan \\
& sumber daya \\
Tidak Mampu & - \\
& uelaku usaha tidak mampu merumuskan visi dan strategi \\
& $-\begin{array}{l}\text { Pegawai tidak mampu memilih metode kerja yang efektif } \\
\end{array}$ \\
& dan efisien
\end{tabular}

Sumber: Data diolah oleh peneliti, tahun 2020

Secara umum para pemilik misi usaha, seperti cara kerja penggunaan usaha/pegawai mempunyai kemampuan mesin/peralatan masih sederhana. sumberdaya yang ada, hal ini terlihat dalam Sertatarget maupun realisasi usaha/produk memanfaatkan sumber daya tenaga yang dihasilkan tidak jelas.

kerja/pegawai maupun sumber daya alam Berdasarkan hasil observasi dan baik pertanian, perkebunan dan lain-lain wawancara dengan pemilik usaha, dan yang tersedia di wilayah Desa Warnasari karyawan UMKM Kabupaten Kecamatan Pangalengan Kabupaten Pangalengan, berikut ini peneliti Bandung, walau pun masih ada para kemukakan kedalam bentuk tabel alasan pemilik usaha/pegawai yang tidak mampu mengenai Potensi yang dimiliki atau yang memilih metode kerja yang efektif dan tidak dimiliki.

efisien serta tidak mampu merumuskan visi

Tabel 3. Potensi

\begin{tabular}{|c|c|}
\hline Potensi & Alasan \\
\hline Potensi yang dimiliki & $\begin{array}{l}\text { - Pelaku usaha memiliki/menggali potensi sumber-sumber } \\
\text { daya } \\
\text { - Pelaku usaha memiliki potensi dalam menghasilkan } \\
\text { produk }\end{array}$ \\
\hline Potensi yang tidak dimiliki & $\begin{array}{l}\text { Pelaku usaha tidak memiliki potensi dalam } \\
\text { mengefektifkan dan mengefisiensikan proses produksi } \\
\text { usaha. }\end{array}$ \\
\hline
\end{tabular}

Sumber: Data diolah oleh peneliti, tahun 2020

Berdasarkan hasil observasi dan wawancara, peneliti menyimpulkan dan menganalisis bahwa para pemilik usaha/pegawai memiliki potensi dalam menghasilkan produk, terlihat dari keberagaman produk/jasa yang dihasilkan oleh 20 pemilik usaha di wilayah Desa Warnasari Kecamatan Pangalengan Kabupaten Bandung, walau pun masih ada para pemilik usaha/pegawai yang tidak memiliki potensi dalam efektivitas dan efisiensi proses produksi, seperti tidak memiliki penjadwalan proses produksi, tidak menjalankan SOP, dan lain-lain.

Berdasarkan hasil observasi dan wawancara dengan pemilik usaha, dan karyawan UMKM Kabupaten Pangalengan, berikut ini peneliti kemukakan kedalam bentuk tabel alasan 
mengenai pengetahuan dan ketrampilan.

Tabel 4. Pengetahuan dan Ketrampilan

\begin{tabular}{ll}
\hline \multicolumn{1}{c}{$\begin{array}{c}\text { Pengetahuan dan } \\
\text { Ketrampilan }\end{array}$} & \multicolumn{1}{c}{ Alasan } \\
\hline Memahami dan terampil & - Memahami tujuan bekerja \\
& - Memahami cara-cara bekerja \\
& - Bekarja sesuai aturan/mekanisme/SOP \\
\hline Tidak Memahami dan Terampil & - Tidak memahami dan terampil dalam pengelolaan \\
& aspek tertentu manajerial usaha \\
& Tidak memahami dan terampil dalam \\
& memanfaatkan atau menggunakan fasilitas usaha. \\
& Tidak memahami dan terampil dalam memilih \\
& metode kerja yang efekti dan efisien. \\
\hline
\end{tabular}

\section{Sumber: Data diolah oleh peneliti, tahun 2020}

Hasil observasi dan wawancara, peneliti menyimpulkan dan menganalisis bahwa para pemilik usaha/pegawai memahami dan terampil dalam tujuan bekerja, yaitu selain menghasilkan produk/jasa, tujuan tersebut untuk meningkatkan kesejahteraan hidup ekonomi keluarga, walau pun masih ada para pemilik usaha/pegawai yang tidak memahami dan terampil dalam pengelolaan manajerial usaha seperti tidak melakukan pencatatan setiap aktivitas usaha berjalan, contoh lain dalam peralatan/mesin masih belum dapat memanfaatkan/ menggunakannya.

Termasuk pemahaman/pengetahuan yang kurang tentang informasi akses permodalan dari pihak pelaksana penyaluran KUR mikro. Berdasarkan hasil observasi dan wawancara dengan pemilik usaha, dan karyawan UMKM Kabupaten Pangalengan, berikut ini peneliti kemukakan kedalam bentuk tabel alasan mengenai penting atau tidaknya motivasi.

Tabel 5. Motivasi

\begin{tabular}{ll}
\hline \multicolumn{1}{c}{ Motivasi } & \multicolumn{1}{c}{ Alasan } \\
\hline Penting & - \\
& - Bekerja secara produktif \\
& - Untuk mecara gairah \\
& - Untuk mencapai kebutuhan \\
& - Untuk lebih mengembangkan usahanya \\
& - Pembagian kerja yang adil dan merata \\
\hline Tidak Penting & - Tidak produktif \\
& - Tidak bergairah \\
& - Pemenuhan kebutuhan seadanya \\
& - Tidak mempunyai target \\
& - Tidak terpikir arah usaha ke depan (seadanya) \\
& - Dominasi pekerjaan oleh pemilik usaha
\end{tabular}

Sumber: Data diolah oleh peneliti, tahun 2020 dimaksud masih ijin di wilayah terbatas (ijin RW 
dll)/belum legal sehingga harapan untuk usaha dapat tumbuh dan berkembang masih

Hasil observasi dan wawancara, peneliti menyimpulkan dan menganalisis bahwa pemberian motivasi kepada para pemilik usaha/pegawai, merupakan suatu kewajiban agar bekerja secara optimal dalam pencapaian hasil. Rendahnya motivasi pelaku usaha/pegawai dapat berpengaruh terhadap kelangsungan kinerja Usaha (UMKM). Terkait dengan implementasi KUR mikro terutama didalam memperoleh dukungan dana, bahwa dengan meminjam dana kepada Bank (kredit), pemilik usaha/pegawai beranggapan dapat membebani pengeluaran secara rutin, selain itu sebagian para pemilik usaha belum memiliki surat ijin usaha dari pemerintah daerah. Contoh UMKM di Kabupaten
Pangalengan surat ijin yang jauh dari pengharapan.

Kualitas lingkungan kerja itu menyangkut lingkungan kerja fisik dan psikis. Lingkungan kerja fisik adalah lingkungan kerja yang dapat dilihat oleh indra para karyawaan, seeperti kondisi kerja, penerangan, kebersihan. Sedangkan lingkungan kerja secara psikis adalah lingkungan kerja yang tidak dapat dilihat oleh indra karyawan, seperti hubungan dengan rekan sekerja dan atasan. Hasil obsrevasi dan wawancara dengan pemilik usaha, dan karyawan UMKM Kabupaten Pangalengan, berikut ini peneliti kemukakan kedalam bentuk tabel alasan mengenai hubungan kerja

\section{Tabel 6. Hubungan Kerja}

\begin{tabular}{ll}
\hline \multicolumn{1}{c}{ Hubungan Kerja } & \multicolumn{1}{c}{ Alasan } \\
\hline Terbangun hubungan kerja & - Pemilik usaha perhatian terhadap pegawai \\
& - Mendengarkan pendapat pegawai \\
& - Menghargai hasil kerja pegawai \\
& - Memuji hasil kerja pegawai \\
& - Rekan kerja mendukung \\
\hline Tidak terbangun hubungan kerja & - Tidak adanya perhatian pemilik usaha \\
& - Pemilik usaha tidak mau mendengar pendapat \\
& pegawai \\
& - Hasil kerja pegawai tidak dihargai \\
& - Tidak ada pujian pekerjaan terhadap pegawai \\
& - Memunculkan konflik \\
& - Dominasi pekerjaan oleh pemilik usaha \\
\hline
\end{tabular}

\section{Sumber: Data diolah oleh peneliti, tahun 2020}

Hasil observasi dan wawancara, peneliti menyimpulkan dan menganalisis bahwa hubungan kerja antara pemilik usaha dengan pegawai terbangun sangat baik, seperti memerhatikan apa yang menjadi keinginan pegawai, rendahnya hubungan kerja para pemilik usaha dengan karyawan terlihat dominasi pemilik untuk melaksanakan pekerjaan, seperti pemilik mengerjakan tugas produksi, juga 
mengerjakan tugas memasarkan, dan lainlain. kemukakan kedalam bentuk tabel alasan mengenai fasilitas (kerja) Hasil observasi dan wawancara dengan pemilik usaha, dan karyawan

UMKM

Tabel 7. Fasilitas (Kerja)

\begin{tabular}{|c|c|}
\hline Fasilitas (Kerja) & Alasan \\
\hline Tersedia fasilitas kerja & $\begin{array}{l}\text { - Pemilik usaha berupaya menyediakan fasilitas untuk } \\
\text { proses produksi atau usaha }\end{array}$ \\
\hline Tidak tersedia fasilitas kerja & $\begin{array}{l}\text { Tidak tersedianya Fasilitas yang dibutuhkan, walau } \\
\text { secara keseluruhan disediakan pemilik. } \\
\text { - } \text { Menurunkan produktivitas }\end{array}$ \\
\hline
\end{tabular}

Sumber: Data diolah oleh peneliti, tahun 2020

Hasil observasi dan wawancara, penting untuk diciptakan karena peneliti menyimpulkan dan menganalisis merupakan persepsi seseorang tentang apa bahwa tersedianya fasilitas kerja yang yang diberikan oleh perusahaan dan disediakan oleh pemilik sangat dibutuhkan, dijadikan dasar bagi penentu tingkah laku fasilitas yang dimaksud berupa fasilitas anggota selanjutnya. Hasil observasi dan keamanan dan keselamatan kerja atau untuk proses produksi. Tidak tersedianya fasilitas kerja dapat menurunkan gairah/motivasi kerja pegawai, seperti minimnya fasilitas kerja keselamatan wawancara dengan pemilik usaha, dan karyawan UMKM Kabupaten Pangalengan, berikut ini peneliti kemukakan kedalam bentuk tabel alasan mengenai Iklim (kerja). dalam alat maupun peralatan. Iklim kerja

Tabel 8. Iklim (Kerja)

\begin{tabular}{ll}
\hline \multicolumn{1}{c}{ Iklim (Kerja) } & \multicolumn{1}{c}{ Alasan } \\
\hline Iklim kerja Kondusif & - Memberikan dukungan \\
& - Menanamkan kejujuran dan penghargaan \\
& - Bertanggung jawab terhadap system keamanan kerja. \\
\hline Iklim kerja Tidak kondusif & - Pelaku usaha menaruh ketidak kepercayaan dan \\
& ketidak terbukaan terhadap pegawai \\
& - Ketidakjelasan tujuan organisasi \\
& - \\
\hline
\end{tabular}

Sumber: Data diolah oleh peneliti, tahun 2020

Hasil observasi dan wawancara, usaha tidak memiliki kejelasan tujuan peneliti menyimpulkan dan menganalisis membuat pegawai kehilangan bahwa secara umum iklim kerja di 20 UMKM sudah kondusif, seperti saling mendukung antar pegawai. Iklim yang tidak kondusif seperti sebagian pemilik

$$
\begin{aligned}
& \text { semangat maupun } \\
& \text { produktivitasnya. } \\
& \text { Hasil observasi dan wawancara } \\
& \text { dengan pemilik usaha/karyawan UMKM }
\end{aligned}
$$


Kabupaten Pangalengan, berikut ini alasan mengenai kebijakan pemimpin peneliti kemukakan kedalam bentuk tabel sebagai berikut :

Tabel 9. Kebijakan Pemimpin

Kebijakan Pemimpin Alasan

\begin{tabular}{ll}
\hline Kebijakan pemimpin tepat & - Menemukan peluang dan dapat dimanfaatkan \\
& - Mengalokasikan berbagai sumber (dana dan daya) \\
& - Mengambil tindakan korektif pada usahanya \\
\hline Kebijakan pemimpin tidak tepat & - Penempatan pegawai yang tidak tepat \\
& - Pemberhentian pegawai \\
& - Tidak mempromosikan pegawai \\
& - Kompensasi langsung tidak sesuai \\
\hline
\end{tabular}

Sumber: Data diolah oleh peneliti, tahun 2020

Berdasarkan hasil observasi dan menempatkan pegawai tidak sesuai wawancara, peneliti menyimpulkan dan keahliannya.

menganalisis bahwa kebijakan yang

Pola kepemimpinan sebagai proses diambil pemilik usaha akan sangat menentukan kelangsungan prospek usahanya. Seperti kebijakan dalam mengalokasikan sumber alam yang tersedia di wilayah Desa Warnasari Kecamatan Pangalengan Kabupaten Bandung. Kebijakan/pengambilan keputusan yang salah seperti menghentikan pegawai tidak tetap, upah yang masih di bawah UMR,

ngarahkan dan mempengaruhi aktivitas yang berkaitan dengan tugas dari anggota kelompok. Berdasarkan observasi dan wawancara dengan pemilik usaha maupun karyawan UMKM Kabupaten Pangalengan, berikut ini peneliti kemukakan kedalam bentuk tabel alasan mengenai Pola kepemimpinan sebagai berikut :

Tabel 10. Pola Kepemimpinan

\begin{tabular}{|c|c|}
\hline Pola Kepemimpinan & $\begin{array}{c}\text { Alasa } \\
\mathbf{n}\end{array}$ \\
\hline Terdapat pola & - Adanya pengarahan pemilik usaha \\
\hline kepemimpinan & - Pengorbanan pribadi demi organisasi \\
\hline $\begin{array}{ll}\text { Tidak } & \text { terdapat } \\
& \text { pola }\end{array}$ & $\begin{array}{l}\text { - Distribusi pengelolaan usaha tidak sama. } \\
\text { - Tidak melibatkan orang lain (pegawai) }\end{array}$ \\
\hline kepemimpinan & \\
\hline
\end{tabular}

Sumber: Data diolah oleh peneliti, tahun 2020

Hasil observasi dan wawancara, peneliti menyimpulkan dan menganalisis 
bahwa para pemilik usaha sudah menerapkan pola kepemimpinannya seperti memberikan arahan-arahan tentang tugas yang dikerjakan oleh pegawai. Pelibatan dan peran pegawai tidak pernah dilakukan oleh para pemilik usaha, karena mempunyai perasaan bahwa usaha tersebut adalah miliknya. Berdasarkan observasi dan wawancara dengan pemilik usaha maupun karyawan UMKM Kabupaten Pangalengan, berikut ini peneliti kemukakan kedalam bentuk tabel alasan mengenai Kondisi Kerja sebagai berikut :

Tabel 11. Kondisi Kerja

\begin{tabular}{|c|c|}
\hline Kondisi Kerja & Alasan \\
\hline Kondisi Kerja Mendukung & $\begin{array}{l}\text { - Pemberian jam istirahat yang cukup } \\
\text { - Pemberian diluar upah bagi pegawai (lama) kerja. } \\
\text { - } \text { Bentuk organisasi sederhana } \\
\text { - } \quad \text { Lingkungan social mendukung } \\
\text { - Keluarga mendukung }\end{array}$ \\
\hline $\begin{array}{l}\text { Kondisi Kerja Tidak } \\
\text { Mendukung }\end{array}$ & $\begin{array}{l}\text { - } \text { Terganggu oleh suara peralatan/mesin } \\
\text { - Penerangan yang kurang } \\
\text { - Upah masih di bawah standar }\end{array}$ \\
\hline
\end{tabular}
Sumber: Data diolah oleh peneliti, tahun 2020

Para pemilik usaha sudah tentunya akan berdampak langsung memberikan waktu yang cukup untuk jam terhadap peningkatan usaha baik istarahat bekerja, uraian pekerjaan peningkatan kapasitas produksi, target dilakukan secara sederhana, keluarga maupun lingkungan sekitar yang maupun realisasi dapat tercapai.

Berkaitan dengan implementasi mendukung merupakan sesuatu hal yang dianggap penting, karena berdampak kepada motivasi, walau pun masih ada para pemilik usaha yang mengabaikan kondisi kerja yang tidak mendukung.

Peneliti menganalisis bahwa dengan adanya Kemampuan baik potensi maupun pengetahuan/ketrampilan, serta dukungan Motivasi dalam berbagai aspek, peneliti menyimpulkan bahwa kedua hal tersebut Kredit Usaha Rakyat (KUR) mikro, peningkatan kinerja usaha (UMKM) harus ditopang oleh kemampuan secara finansial maupun permodalan. Hal tersebut selalu diupayakan melalui peran pemerintah kepada pemilik usaha (UMKM) dalam memperoleh bantuan berupa kredit maupun pinjaman-pinjaman dana dengan harapan usaha yang dilakukan dapat tumbuh dan berkembang. 


\section{KESIMPULAN}

1. Implementasi kebijakan KUR pada UMKM Di Kabupaten Bandung, adanya kemampuan baik potensi maupun pengetahuan/ketrampilan, serta dukungan motivasi dalam berbagai aspek, kedua hal tersebut tentunya akan berdampak langsung terhadap peningkatan usaha baik peningkatan kapasitas produksi, target maupun realisasi dapat tercapai. Berkaitan dengan implementasi Kredit Usaha Rakyat (KUR) mikro, peningkatan kinerja usaha (UMKM) harus ditopang oleh kemampuan secara finansial maupun permodalan. Hal tersebut selalu diupayakan melalui peran pemerintah kepada pemilik usaha (UMKM) dalam memperoleh bantuan berupa kredit maupun pinjaman-pinjaman dana dengan harapan usaha yang dilakukan dapat tumbuh dan berkembang.

2. Analisis Implementasi Kebijakan, secara teknis/operasional belum terlaksana dengan baik, baik dari aspek komunikasi, Sumber daya (manusia) dan sumber daya lain (finansial), Disposisi (Sikap Birokrasi/Pelaksana) serta Struktur Birokrasi Organisasi (mekanisme/pembagian tugas), namun secara keseluruhan keempat aspek ini sudah dijalankan oleh pihak pelasana (BRI).
3. Analisis Kinerja (UMKM) secara umum sudah dilaksanakan oleh para pemilik usaha, namun dalam kemampuan pemahaman dan pengetahuan, serta motivasi rendah para pelaku usaha dalam mendapatkan informasi yang berhubungan dengan Kredit Usaha Rakyat mikro.

\section{DAFTAR PUSTAKA}

Abdulwahab. S. 1996. Pengantar Analisi Kebijaksanaan Negara, Rineka Cipta. Jakarta. 2008. Analisis Kebijakan

: dari formulasi ke implementasi kebijaksanaan negara. Bumi Aksara. Jakarta.

Bustami et.al.2007. Mari Membangun Usaha Mandiri. Yogyakarta : Graha Ilmu.

Cascio. WF. 1992. Managing Human Resources. Productivity Quality of Work. New York: McGraw-Hill/Irwin.

Creswell, John W.2010.Research Design : Pendekatan Kualitatif, Kuantitatif dan Mixed.Diterjemahkan Oleh : Achmad Fawald, Yogyakarta : Pustaka Pelajar.

David.R.Fred, 2008.Strategic Management Manajemen Strategis.Jakarta : Salemba Empat.

Dharma, Agus. 2003.Manajemen Supervisi cetakan lima. Jakarta. Raja Grafindo Persada.

Hamali.Y.Arif . 2019. Pemahaman Praktis Administrasi, Organisasi, dan Manajemen. 
Prenadamedia Grup. Jakarta.

Lupioyadi. Handani. 2006. Manajemen

Pemasaran Jasa. Salemba Empat. Jakarta.

Mangkunegara. P. Anwar, 2005.

Manajemen Sumber Daya Manusia

Perusahaan. Remaja Rosdakarya. Bandung

Moleong.J.Lexy. 1998.Metodologi

Penelitian Kualitatif. Bandung : Remaja

Rosdakarya

Pambudy Racmat et.al.2017.

Kewirausahaan dan Manajemen Bisnis

Kecil. Bogor : Idemedia Pustaka Utama.

Purwanto.H.Bambang

$\&$

Afandi.N.Muhamad.2018.Manajemen

Strategi

Sektor

Publik.Bandung.Universitas Pasundan.

Sugiyono.2018.Metode Penelitian

Bisnis.Bandung : Alfabeta

Sumiati. Imas. 2017. Empat Proses Desain

Dalam Kinerja Organisasi. Kencana

Utama. Bandung.

Sutrisno. Edy. 2015. Manajemen Sumber

Daya Manusia. Kencana-Prenadamedia

Grup. Jakarta.

Wibowo.2010. Manajemen Kinerja.

Jakarta: Raja Grafindo Persada.

Willson and heyyel. 1987. Hand Book of

Modern Office Management and

Administration Service. Mc Graw Hill Inc.

New Jersey.

Sumber lain :

Undang-undang Nomor 2o Tahun 2008

tentang Usaha Mikro, Kecil, dan

Menengah.
Kepres Nomor 14 Tahun 2015 tentang Komite Kebijakan Pembiayaan Bagi Usaha Mikro, Kecil dan Menengah.

Kepres Nomor 19 Tahun 2015 sebagai revisi Kepres Nomor 14 Tahun 2015 tentang Perubahan Atas Kepres Nomor 14 Tahun 2015 tentang Komite Kebijakan Pembiayaan Bagi Usaha Mikro, Kecil dan Menengah.

Permen Koordinator Bidang Perekonomian Nomor 11 Tahun 2017 tentang Pedoman Pelaksanaan Kredit Usaha Rakyat.

Permenkeu Nomor 180/PMK.05/2017 tentang Tata Cara Pembayaran Subsidi Bunga untuk KUR. 